
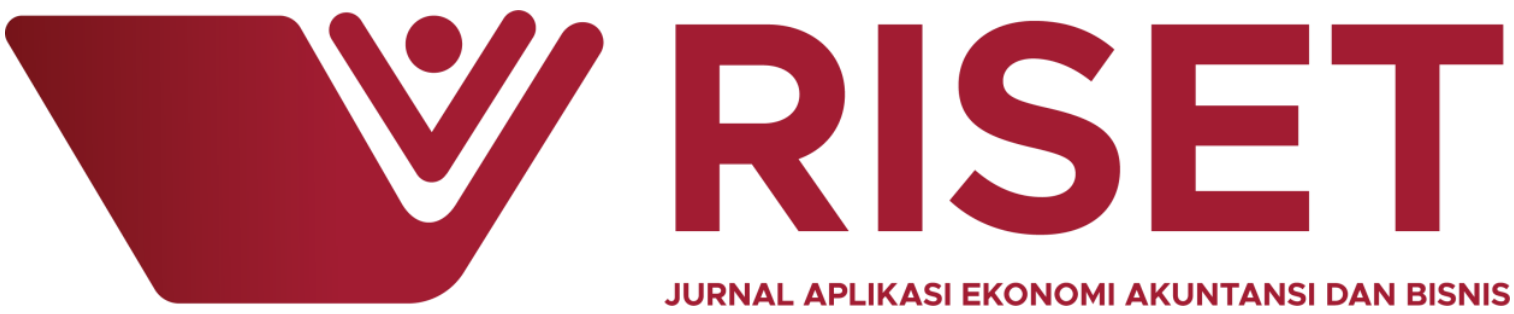

JURNAL APLIKASI EKONOMI AKUNTANSI DAN BISNIS

\title{
FACTORS AFFECTING THE MANAGEMENT OF INCOME
}

\author{
Nur Elian Rahma Rucita ${ }^{1)}$, Riki Sanjaya ${ }^{2)}$ \\ ${ }^{1,2)}$ STIE Trisakti (Trisakti School of Management)
}

\begin{abstract}
ARTICLE INFO

Factors Affecting The Management Of Income

The purpose of this research is to examine institutional ownership, managerial ownership, the board of commissioner frequency meeting, audit committee frequency meeting, firm size, leverage, audit quality, and independent commissioner in affecting earning management in manufacturing companies listed in Indonesia Stock Exchange. This research used 37 listed manufacturing companies in Indonesia Stock Revised: Exchange, and the data were selected using the purposive sampling method during the research period 2017-2019. Data were analyzed using multiple regression methods. The research results show that leverage influence earning management. In contrast, for institutional ownership, managerial ownership, the board of commissioner frequency meeting, audit committee frequency meeting, firm size, audit quality, and the independent commissioner has no considerable influence on earning management.
\end{abstract}

Keywords: earning management, leverage, institutional ownership, managerial ownership

Email: Nurelianrahmarucita@gmail.com ${ }^{12}$, Riki_Sanjaya12@yahoo.com ${ }^{2)}$

\section{INTRODUCTION}

The company's responsibility to stakeholders at the end of the period is to present the financial statements. Financial reports have a very important role for users of financial statements as an assessment of company performance. The purpose of making financial reports is to provide useful results on the use of company resources to parties who need information such as creditors, investors, management, and the government.

Investors in investing use financial reports as a basis for decision making, an important element contained in financial reports is information about earnings. Investors pay attention to gaining information, it makes the company was motivated to produce good financial statements so that the company's performance is considered good by 
investors. The attention to profit will certainly be used to make profits that will benefit the company utilizing earnings management (Indriastuti, 2012).

Companies can carry out earnings management in several ways, such as exploiting gaps to make accounting estimates, changing the accounting method used, and making period shifts in recording costs or revenues. So that earnings management is not always related to information manipulation. According to (Subramanyam, 2014) earnings management is divided into several types, namely income smoothing, taking a bath, increasing income. Earnings management is usually carried out to get a bonus, for the benefit of the government, and also at the time of the initial public offering.

This research is a development from previous research conducted by Saftiana et al. (2017). Independent variables used are institutional ownership, frequency of board meetings, audit committee meeting frequency, the size of the company, and leverage. These variables are used to determine whether there is an influence on earnings management.

The difference between this study and the research conducted by Saftiana et al. (2017), the first is the addition of independent variables, in whom is the variable quality of audits of Laily (2017), variable independent board of Nurlis et al. (2020) and the use of pro-action managerial ownership of Farouk \& Bashir (2017). The reason for adding the audit quality variable and the independent board of commissioners is to want to know the effect of audit quality and independent board of commissioners on earnings management in the hope of improving the research model in predicting the dependent variable. The second difference is that the previous research period used the 2010-2014 research period, while this study used the 2017-2019 research period. The third difference is that the previous study used the population of LQ45 companies listed on the Indonesia Stock Exchange, while this study used manufacturing companies listed on the Indonesia Stock Exchange, with the expansion of the research population it is hoped that the results of the study will more represent the research population.

\section{LITERATURE REVIEW}

\section{Agency Theory}

Agency theory defines the relationship between conflicting parties, namely the principal and the agent. In which the principal is a shareholder who wants to know the activities undertaken by the management which acts as an agent. The relationship between the principal and the agent can make the difference for each party because the principal and agencies have their interests (Scott, 2015).

Their condition information imbalance that occurs between agents and principals, so that the position of an agent who is better informed than the principal company, it is used by agents to manipulate the financial statements. This difference in interests is called the agency problem (Arifin \& Destriana, 2016).

\section{Signal Theory}

Information is very important for investors and business people because information can be an understanding of the past, present, or future. The issuance of financial reports is used by managers to provide information to interested parties.

Signal theory explains that the signals given by management are a way to reduce the asymmetry of information between enterprises and outsiders. The reduction of the information asymmetry between agents and principal will result in a reduction in the company's actions do earnings management. Signal theory can minimize earnings management actions (Yunietha \& Palupi, 2017). 


\section{Institutional Ownership and Earnings Management}

Institutional ownership is the ownership of company shares owned by institutional investors. Institutions that become institutional investors are non-financial institutions and financial institutions (Saftiana et al., 2017). The Institution's professional investor presence can monitor the company's business activities and make managers doing business in a transparent manner (Effendi \& Daljono, 2013). The existence of institutional ownership has a role to increase supervision in detecting the possibility of earnings management (Asward \& Lina, 2015). Institutional professional investors in monitoring management are more effective than individual investors (Aygun, Ic, \& Sayim, 2014).

$\mathrm{H}_{1}$ : Institutional ownership affects earnings management.

\section{Managerial Ownership and Earnings Management}

Share ownership is owned by management such as the board of commissioners and board of directors in addition to shares owned by principals, the public, and institutional parties (Paramitha \& Firnanti, 2018). With share ownership by management, it can improve management performance and present quality financial reports (Yogi \& Damayanthi, 2016). Managerial ownership can act as a company's internal supervisor (Chen \& Steiner, 1999). The higher the share ownership owned by management, it is expected that it will reduce the possibility of earnings management (Napitupulu, 2012).

$\mathrm{H}_{2}$ : Managerial ownership effect on earnings management.

\section{Frequency of Commissioner Board Meetings and Earnings Management}

The importance of a meeting in determining the effectiveness of the board of commissioners in running, monitoring, and controlling company operations (Saftiana et al., 2017). The meeting media is used by the board of commissioners in communicating and coordinating its members to carry out their duties as supervisors (Prastiti \& Meiranto, 2013). Chen et al. (2006) stated that more and more meetings held by the Board of Commissioner then will reduce the possibility of manipulation, due to the frequency of board meetings do become more able to solve problems related to the company's financial statements.

$\mathrm{H}_{3}$ : The frequency of board meetings affects earnings management.

\section{Frequency of Audit Committee Meetings and Earnings Management}

The audit committee holds meetings to increase the effectiveness in supervising management and does not try to maximize its interests (Prastiti \& Meiranto, 2013). By holding regular audit committee meetings, it will make better oversight for reporting financial reports (Xie, Davidson, \& DaDalt, 2003). Bapepam recommends that audit committee meetings be held four times a year. The more often the audit committee meetings are held, the more active they will be in discussing company activities and evaluating financial statements so that it will reduce earnings management practices. (Sari, 2017).

$\mathrm{H}_{4}$ : The frequency of audit committee meetings affects earnings management.

\section{Company Size and Earnings Management}

Company size is a scale that explains the ratio of the size of the business of the company (Launa \& Respati, 2014). The size of a company can be seen based on the company's total assets (Agustia \& Suryani, 2018). Companies with large sizes usually get more attention from the public and in publishing financial reports they will be more 
careful Florencia \& Susanty (2019). Christiani \& Nugrahanti (2014) state that companies with large size are likely not to practice earnings management because many parties observe these financial statements.

$\mathrm{H}_{5}$ : Firm size affects earnings management.

\section{Leverage and Profit Management}

Leverage ratios are commonly used by companies in describing the source of the company's operating funds and showing the risks the company will face (Agustia, 2013). The leverage ratio is used to determine assets that are financed by debt (Pradipta, 2019). The greater the value of the leverage ratio, the higher the risk for lenders to get back all their investment (Florencia \& Susanty, 2019).

$\mathrm{H}_{6}$ : Leverage affects earnings management.

\section{Audit Quality and Earnings Management}

To reduce conflicts between agents and principals companies should require audit services to audit the financial statements (Yunietha \& Palupi, 2017). The parameter used as a measure of audit quality is the size of KAP, namely KAP big four and KAP non-big four (Firnanti, 2017). With the existence of good quality audits carried out by auditors, it is expected to be able to reduce earnings management actions (Annisa \& Hapsoro, 2017).

$\mathrm{H}_{7}$ : Audit quality affects earnings management.

\section{Independent Commissioner and Earnings Management}

The independent board of commissioners is a party that has no relationship between the company and other members of the board of directors or commissioners (Firnanti, 2017). The independent board of commissioners has the responsibility or role to monitor the activities of the board of directors (Almalita, 2017). The independent board of commissioners is also tasked with ensuring that the strategies used by the company are following applicable regulations (Arifin \& Destriana, 2016).

$\mathrm{H}_{8}$ : The independent board of commissioners affects earnings management.

\section{RESEARCH METHOD}

\section{Forms and Objects of Research}

The sample selection used the purposive sampling method. The object of this research is manufacturing companies listed on Indonesia Stock Exchange from the year 2017 up to 2019. Criteria for sampling used can be seen in Table 1 below:

Table 1: Research Sample Selection Procedure

\begin{tabular}{llcc}
\hline \multicolumn{1}{c}{ Information } & $\begin{array}{c}\text { Total } \\
\text { Company }\end{array}$ & $\begin{array}{c}\text { Total } \\
\text { Data }\end{array}$ \\
\hline 1. & $\begin{array}{l}\text { Manufacturing companies consistently listed on } \\
\text { the Indonesia Stock Exchange during the 2017- }\end{array}$ & 134 & 402 \\
2019 period \\
Manufacturing companies that do not use \\
Rupiah in their financial statements during the \\
2017-2019 period \\
Manufacturing companies that did not present \\
financial statements for the period ending
\end{tabular}


December 31 during the 2017-2019 period

4. Manufacturing companies that do not have institutional shareholdings during the 20172019 period

5. Manufacturing companies that do not have managerial share ownership during the 20172019 period

6. Manufacturing companies that do not disclose the frequency of board of commissioners meetings in their annual reports during the 2017-2019 period

7. Manufacturing companies that do not disclose the frequency of audit committee meetings in their annual reports during the 2017-2019 period

Number of sample companies

Source: data collected

\section{Variable and Measurement Data}

\section{Profit Management}

Earnings management is the dependent variable used in this study. Earnings management in this study is measured using discretionary accruals. Identifying earnings management in this study using the Modified Jones Model, as research conducted by Saftiana et al. (2017). The steps to obtain discretionary accruals are as follows:

$\mathrm{TAC}=$ Net income - Cash flow from operating

$$
\begin{aligned}
& \frac{\mathrm{TAC}_{\mathrm{t}}}{\mathrm{A}_{\mathrm{t}-1}}=\alpha_{1}\left(\frac{1}{\mathrm{~A}_{\mathrm{t}-1}}\right)+\alpha_{2}\left(\frac{\Delta \mathrm{REV}_{\mathrm{t}}-\Delta \mathrm{REC}_{\mathrm{t}}}{\mathrm{A}_{\mathrm{t}-1}}\right)+\alpha_{3}\left(\frac{\mathrm{PPE}}{\mathrm{A}_{\mathrm{t}-1}}\right)+\mathrm{e} \\
& \mathrm{NDA}_{\mathrm{t}}=\alpha_{1}\left(\frac{1}{\mathrm{~A}_{\mathrm{t}-1}}\right)+\alpha_{2}\left(\frac{\Delta \mathrm{REV}_{\mathrm{t}}-\Delta \mathrm{REC}_{\mathrm{t}}}{\mathrm{A}_{\mathrm{t}-1}}\right)+\alpha_{3}\left(\frac{\mathrm{PPE}}{\mathrm{A}_{\mathrm{t}-1}}\right) \\
& \mathrm{DA}_{\mathrm{t}}=\left(\frac{\mathrm{TAC}_{\mathrm{t}}}{\mathrm{A}_{\mathrm{t}-1}}\right)-\mathrm{NDA}_{\mathrm{t}}
\end{aligned}
$$

Information :

$\mathrm{TACt}=$ Total accruals in period $\mathrm{t}$

At-1 = Total assets at the end of $\mathrm{t}-$ year $\mathrm{t}-1$

PPEt $=$ Gross property plant and equipment in year $\mathrm{t}$

$\triangle \mathrm{RECt}=$ Change in accounts receivable from year $\mathrm{t}-1$ to year $\mathrm{t}$

$\triangle \mathrm{REVt}=$ Change in income from year $\mathrm{t}-1$ to year $\mathrm{t}$

NDAt $=$ Nondiscretionary accruals in period $t$

DAt = Company's discretionary accrual in period $\mathrm{t}$

\section{Institutional Ownership}

Institutional ownership is share ownership by parties in the form of nonfinancial institutions and financial institutions (Saftiana et al., 2017). Proxy for variable 1 institutional ownership is taken from research Saftiana et al. (2017). $\mathrm{KI}=$ Number of shares owned by institutional shareholders/total shares outstanding 


\section{Managerial Ownership}

Managerial ownership is measured using the proportion of shares owned by the directors according to research (Farouk \& Bashir, 2017).

$\mathrm{KM}=\%$ The number of shares held by the board of directors

\section{Board of Commissioners Meeting Frequency}

The frequency of board meetings in the research using the dummy variable. The proxy is used to measure the frequency of board meeting variables drawn from research Saftiana et al. (2017).

$1=$ BOARDMEET $>$ Average Sample

$0=$ BOARDMEET $<$ Average Sample

\section{Audit Committee Meeting Frequency}

Frequency of meetings of the audit committee in research using the dummy variable. The proxy used to measure the variable frequency of audit committee meetings is taken from the research of Saftiana et al. (2017).

$1=$ ACMEET $>$ Average Sample

$0=$ ACMEET $<$ Average Sample

\section{Company Size}

Agustia \& Suryani (2018) states that a company the size of company can be seen from the total assets of her. The proxy for the firm size variable is taken from the research of Saftiana et al. (2017).

Size $=$ LnTotal Asset

\section{Leverage}

Leverage is used to determine the total assets financed by debt (Naftalia \& Marsono, 2013). The proxy for the leverage variable is taken from the research of Saftiana et al. (2017).

LEV = Total of Liabilities/Total Asset

\section{Audit Quality}

Quality audits in this study using a dummy variable. The proxies used to measure audit quality variables are taken from Laily's (2017) research.

1 = bigfour KAP

$0=$ not bigfour KAP

\section{Independent Board of Commissioners}

Independent commissioners are measured by dividing the total independent commissioners by the total commissioners. The proxy for the independent board of commissioners is taken from the research of Nurlis et al. (2020).

$\mathrm{BIND}=$ Total Independent Commissioners/Total Commissioners

\section{Analysis Technique}

This study using multiple regression for the data analysis method. Here's the regression equation:

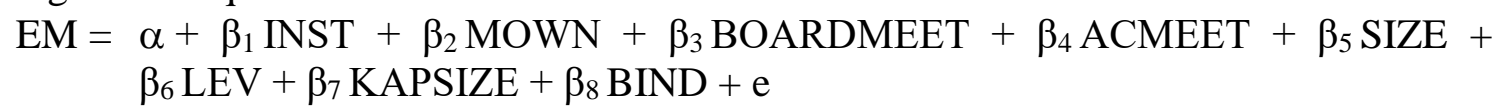


Information :

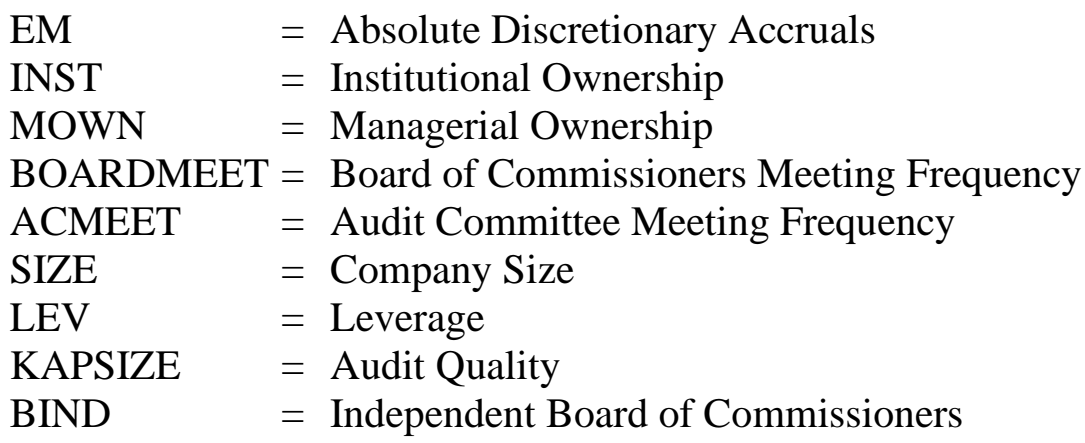

\section{RESULT AND DISCUSSION}

The results of the classic assumption test can be seen in the following table 2 :

Table 2: Multicollinearity Test Results

\begin{tabular}{lccl}
\multicolumn{1}{c}{ Variable } & Tolerance & VIF & Conclusion \\
\hline INST & 0.440 & 2,271 & Multicollinearity does not occur \\
MOWN & 0.473 & 2,113 & Multicollinearity does not occur \\
BOARDMEET & 0.891 & 1,122 & Multicollinearity does not occur \\
ACMEET & 0.771 & 1,296 & Multicollinearity does not occur \\
SIZE & 0.546 & 1,830 & Multicollinearity does not occur \\
LEV & 0.857 & 1,166 & Multicollinearity does not occur \\
KAPSIZE & 0.480 & 2,085 & Multicollinearity does not occur \\
BIND & 0.746 & 1,341 & Multicollinearity does not occur \\
\hline
\end{tabular}

Source: Results of Data Processing through SPSS v. 25

Table 3: Heteroscedasticity Test Results

\begin{tabular}{lcl} 
Variable & Sig & Conclusion \\
\hline INST & 0.329 & Heteroscedasticity does not occur \\
MOWN & 0.680 & Heteroscedasticity does not occur \\
BOARDMEET & 0.747 & Heteroscedasticity does not occur \\
ACMEET & 0.437 & Heteroscedasticity does not occur \\
SIZE & 0.058 & Heteroscedasticity does not occur \\
LEV & 0,000 & Heteroscedasticity occurs \\
KAPSIZE & 0.366 & Heteroscedasticity does not occur \\
BIND & 0.102 & Heteroscedasticity does not occur \\
\hline
\end{tabular}

Source: Results of Data Processing through SPSS v. 25

Table 4: Autocorrelation Test Results

Sig.

Conclusion

\begin{tabular}{ccc}
\hline Res_2 & 0.910 & There is no autocorrelation \\
\hline Source: Results of Data Processing through SPSS v. 25
\end{tabular}


The results of multiple regression tests can be seen in Table 5 below:

Table 5: Multiple Regression Test Results

\begin{tabular}{lcc}
\hline \multicolumn{3}{c}{ Unstandardized Coefficients } \\
Variable & B & Sig. \\
& & \\
\hline (Constants) & 0.228 & 0.065 \\
INST & 0.016 & 0.629 \\
MOWN & 0.015 & 0.696 \\
BOARDMEET & -0.004 & 0.754 \\
ACMEET & 0.016 & 0.235 \\
SIZE & -0.008 & 0.073 \\
LEV & 0.101 & 0.001 \\
KAPSIZE & 0.001 & 0.933 \\
BIND & $-0,025$ & 0.644 \\
a Dependent Variable: EM . & & \\
R $^{2}$ 0.395, adjusted R ${ }^{2} 0.090$, F 2.357, Sig. 0.023. \\
P - Value (Significance) 0.05 .
\end{tabular}

Institutional Ownership (INST) shows coefficient regresi amounted to 0.016 and the value of sig. amounting to $0.629>0.05$ so it can be concluded that $\mathrm{Ha}_{1}$ is not accepted. These results are consistent with the research of Saftiana et al. (2017) and Firnanti (2017) which refers to show that there is no influence between institutional ownership with earnings management, it may be caused due to the main focus of institutional investors to obtain current earnings and cannot oversee the management of profit (Florencia \& Susanty, 2019).

Managerial Ownership (MOWN) shows a regression coefficient of 0.015 and the value of sig. equal to $0.696>0.05$. It can be concluded that $\mathrm{Ha}_{2}$ is not accepted. These results show that there is no influence of managerial ownership with earnings management, this may be due regardless of the percentage of shares owned by the management company not affect earnings management practices (Yunietha \& Palupi, 2017), except that the percentage of the number of managerial ownership is relatively small so it does not affect earnings management (supposedly managerial ownership is expected to prevent earnings management, because the higher the percentage, the more management feels that they own the company so that they will carry out better supervision and avoid earnings management). These results are in line with research conducted by Yunietha \& Palupi (2017).

The meeting frequency of the board of commissioners (BOARDMEET) has a regression coefficient of -0.004 and a sig. equal to $0.754>0.05$. It can be concluded that $\mathrm{Ha}_{3}$ is not accepted. These results point to no effect frequency of board meetings with earnings management, it may be caused because the commissioners are part-time and only met once in a while and do not know each other well other and have less experience in the business of the company (Saftiana et al., 2017). These results are following the research conducted by Saftiana et al. (2017) and Ichsany \& Husain (2018).

The frequency of audit committee meetings (ACMEET) has a regression coefficient of 0.016 and a sig. equal to $0.235>0.05$. It can be concluded that $\mathrm{Ha}_{4}$ is not accepted. These results show no influence frequency of meetings of the audit committee on earnings management, it may be caused due to the size of the number of audit 
committee meetings did not have an impact on earnings manipulation performed by the management company, might still many companies that do not follow the regulation of Bapepam to conduct meetings once in three months or four times a year (Prabowo, 2014). Besides, the company may hold an audit committee meeting only as a formality so that it does not affect earnings management, although it is hoped that the existence of an audit committee can prevent this in substance. These results are following the research of Saftiana et al. (2017) and Prabowo (2014).

Company size (SIZE) has a value of regression coefficient of -0.008 and the value of sig. $0.073>0.05$, so it can be concluded that $\mathrm{Ha}_{5}$ is not accepted. These results point to there was no effect of firm size on earnings management, it may be caused due to the size of the company can not be used as a means of measuring the occurrence of acts management earnings due to large or small remains potentially earning management (Arifin \& Destriana, 2016). These results are following the research conducted by Saftiana et al. (2017) and Florencia \& Susanty (2019).

Leverage (LEV) has a regression coefficient of 0.101 and the value of sig. $0.001<$ 0.05 , so it can be concluded that $\mathrm{Ha}_{6}$ is accepted. These results align with research Arifin \& Destriana (2016) and Almalita (2017) which refers to that the variable leverage-positive effect on earnings management, since the ratio leverage the high describe the debts owed by greater than its assets and therefore companies earning management (Agustia, 2013). According to the theory signal companies will tend to appoint excellent performance, but the leverage is high then the risk to the company is also high that the company will make profit management actions to compensate for the user's perception of financial statements.

Quality of audit (KAPSIZE) has a regression coefficient of 0.001 and the value of sig. $0.933>0.05$. It is concluded that $\mathrm{Ha}_{7}$ is not accepted. These results show no effect of audit quality on earnings management, it may be caused due to the examination of financial statements by KAP big four did not rule out the company earning management (Arifin \& Destriana, 2016). These results are in line with research conducted by Christiani \& Nugrahanti (2014) and Laily (2017).

The board of independent commissioners (BIND) has a regression coefficient value of -0.025 and a significance value of $0.644>0.05$, so it can be concluded that $\mathrm{Ha}_{8}$ is not accepted. These results show no influence independent board to earnings management, it may be caused due to the independent board at the company merely formal provision only, so it is not effective in providing surveillance to prevent earnings management (which should hopefully prevent profit management). These results are in line with the research of Nurlis et al. (2020) and Alexander \& Christina (2017).

\section{CONCLUSION}

This research was conducted to obtain empirical evidence regarding the effect of institutional ownership, managerial ownership, frequency of board meetings, frequency of audit committee meetings, firm size, leverage, audit quality, and independent board of commissioners on earnings management. It can be concluded that the results of this study show that leverage has a significant influence on earnings management. Institutional ownership, managerial ownership, frequency of board meetings, audit committee meeting frequency, size, quality audits, and the independent board do not affect earnings management.

This study has implications for companies to pay attention and keep the ratio of the leverage of companies that influence earnings management that companies are protected from the practice of earnings management, for investors to 
$\mathrm{m}$ taking account of the ratio of leverage when investing in listed companies because the decision right is taken based on financial statements that represent the right conditions economic issuers one of which is the income statement that is free from the profit management, for the regulator to be able to exercise more effective to determine the factors that influence profit management, the effective oversight expected more and more companies are going to avoid the practice of earnings management and encourage companies presenting financial statements that represent the right economic conditions itself.

There are several limitations of this study is the observation period was only three years, the data residual in this study is not normal, there is the problem of heteroskedasticity and value adjusted $\mathrm{R}^{2}$ low. Based on the limitations that the researchers wanted to give some recommendations that may help researchers further research related to earnings management, which is a renewal period of observation, adding the amount of data residuals to solve the data residuals are not normally distributed, perform the transformation of data to avoid of the occurrence of heteroscedasticity and adding independent variables which are expected to have an influence on earnings management such as ROA and growth.

\section{REFERENCES}

Agustia, D. (2013). The Effect of Free Cash Flow and Audit Quality on Earnings Management. AKRUAL: Accounting Journal, 4(2), 105. https://doi.org/10.26740/jaj.v4n2.p105-118

Agustia, Y. P., \& Suryani, E. (2018). The Influence of Company Size, Company Age, Leverage, and Profitability on Earnings Management (Study of Mining Companies Listed on the Indonesia Stock Exchange 2014-2016 Period). ASET Journal (Accounting Research), 10(1), 63-74. https://doi.org/10.17509/jaset.v10i1.12571

Alexander, N., \& Christina, S. (2017). The Effect of Corporate Governance, Ownership and Tax Aggressiveness on Earnings Management. Accounting and Finance Review, 2(4), 40-45.

Almalita, Y. (2017). The Influence of Corporate Governance and Other Factors on Earnings Management. Journal of Business and Accounting, 19(2), 183-194. https://doi.org/10.34208/jba.v19i2.271

Annisa, A. A., \& Hapsoro, D. (2017). The Effect of Audit Quality, Leverage, and Growth on Earnings Management Practices. Accounting Journal, 5(2), 99-110. https://doi.org/10.24964/ja.v5i2.272

Arifin, L., \& Destriana, N. (2016). The Influence of Firm Size, Corporate Governance, and Company Characteristics on Earnings Management. Journal of Business and Accounting, 18(1), 84-93. https://doi.org/10.34208/jba.v18i1.41

Asward, I., \& Lina. (2015). The Effect of the Corporate Governance Mechanism on Earnings Management with the Conditional Revenue Model Approach. Journal Technology Management, 14(1), 15-34. https://doi.org/10.12695/jmt.2015.14.1.2

Aygun, M., Ic, S., \& Sayim, M. (2014). The Effects of Corporate Ownership Structure and Board Size on Earnings Management: Evidence from Turkey. International Journal of Business and Management, 9(12), 123-132. https://doi.org/10.5539/ijbm.v9n12p123

Chen, C. R., \& Steiner, T. L. (1999). Managerial Ownership and Agency Conflicts: A Nonlinear Simultaneous Equation Analysis of Managerial Ownership, Risk Taking, Debt Policy, and Dividend Policy. The Financial Review, 34(1), 119-136. 
https://doi.org/10.1111/j.1540-6288.1999.tb00448.x

Chen, G., Firth, M., Gao, D. N., \& Rui, O. M. (2006). Ownership Structure, Corporate Governance, andFfraud: Evidence from China. Journal of Corporate Finance, 12(3), 424-448. https://doi.org/10.1016/j.jcorpfin.2005.09.002

Christiani, I., \& Nugrahanti, Y. W. (2014). The Effect of Audit Quality on Earnings Management. Journal of Accounting and Finance, 16(1), 52-62. https://doi.org/10.9744/jak.16.1.52-62

Effendi, S., \& Daljono. (2013). The Influence of Corporate Governance and Auditor Quality on Earnings Management. Diponegoro Journal of Accounting, 2(3), 1-14.

Farouk, M. A., \& Bashir, N. M. (2017). Ownership Structure and Earnings Management of Listed Conglomerates in Nigeria. Journal of Accounting and Finance (IPJAF), $1(4), 42-54$.

Firnanti, F. (2017). The Influence of Corporate Governance and Other Factors on Earnings Management. Journal of Business and Accounting, 19(1), 66-80. https://doi.org/10.34208/jba.v19i1.66

Florencia, \& Susanty, M. (2019). Corporate Governance, Free Cash Flows, and Profit Management. Journal of Business and Accounting, 21(2), 141-154. https://doi.org/10.34208/jba.v21i2.615

Ichsany, S. W. M. N., \& Husain. (2018). The Frequency of Meetings of the Board of Commissioners and the Audit Committee on Earnings Management Using a NonDiscretionary Ac. MBIA, 17(2), 34-46. https://doi.org/10.33557/mbia.v17i2.343

Indriastuti, M. (2012). Analysis of Auditor Quality and Corporate Governance on Earnings Management. Eksistansi, 4(2), 1-11.

Laily, N. (2017). The Effects of Good Corporate Governance and Audit Quality on Earnings Management. Journal of Accounting and Business Education, 1(1), 134143. https://doi.org/10.26675/jabe.v1i1.9754

Launa, E., \& Respati, N. W. (2014). The Effect of Corporate Governance Mechanisms and Company Size on Earnings Management (Companies Against Earnings Management). Jurnal Reviu Akuntansi Dan Keuangan (JRAK), 4(1), 507-524. https://doi.org/10.22219/jrak.v4i1.4923

Naftalia, V. C., \& Marsono. (2013). The Effect of Leverage on Earnings Management with Corporate Governance as a Moderating Variable. Diponegoro Journal of Accounting, 2(3), 1-8.

Napitupulu, R. H. E. (2012). Factors Affecting Profit Management in Manufacturing Companies Listed on the Indonesia Stock Exchange. Journal of Business and Accounting, 14(2a), 61-78. https://doi.org/10.34208/jba.v14i2a.262

Nurlis, Indriawati, F., Ariani, M., \& Prihanto, H. (2020). Earnings Management: Empirical Evidence on Determinants in Indonesia. European Journal of Business and Management, 12(3), 27-32. https://doi.org/10.7176/EJBM/12-3-04

Paramitha, L., \& Firnanti, F. (2018). The Influence of Ownership Structure and Other Factors on Earnings Management). Journal of Business and Communication, 5(2), 116-123.

Prabowo, D. A. (2014). The Influence of Independent Commissioners of the Audit Committee, Size and Number of Audit Committee Meetings on Earnings Management (Case Study of Manufacturing Companies Listed on the Indonesia Stock Exchange 2010-2012). Accounting Analysis Journal, 3(1), 90-99. https://doi.org/10.15294/aaj.v3i1.4190

Pradipta, A. (2019). Earnings Management: Corporate Governance and Free Cash Flow. Journal of Business and Accounting, 21(2), 205-214.

Prastiti, A., \& Meiranto, W. (2013). Effect of the Characteristics of the Board of 
Commissioners and the Audit Committee on Earnings Management. Diponegoro Journal of Accounting, 2(4), 1-12.

Saftiana, Y., Mukhtaruddin, Putri, K. W., \& Ferina, I. S. (2017). Corporate Governance Quality, Firm Size and Earnings Management: Empirical Study in Indonesia Stock Exchange. Investment Management and Financial Innovations, 14(4), 105120. https://doi.org/10.21511/imfi.14(4).2017.10

Sari, A. L. (2017). Company Characteristics, Corporate Governance, and Earnings Management. Journal of Accounting Business, 15(2), 229-245. https://doi.org/10.24167/jab.v16i1.1364

Scott, W. R. (2015). Financial Accounting Theory (7th ed.). Toronto: Pearson Canada Inc.

Subramanyam, K. R. (2014). Financial Statement Analysis. In McGraw-Hill Education (11th ed.). New York: McGraw-Hill Education.

Xie, B., Davidson, W. N., \& DaDalt, P. J. (2003). Earnings Management and Corporate Governance: The Role of The Board and The Audit Committee. Journal of Corporate Finance, 9(3), 295-316. https://doi.org/10.1016/S09291199(02)00006-8

Yogi, L. M. D. P., \& Damayanthi, I. G. A. E. (2016). The Influence of Free Cash Flow, Capital Adequacy Ratio, and Good Corporate Governance on Earnings Management). E-Journal Accounting Udayana University, 15(2), 1056-1085.

Yunietha, \& Palupi, A. (2017). The Influence of Corporate Governance and Other Factors on Profit Management in Non-Financial Public Companies. Journal of Business and Accounting, 19(1a), 292-303. 